J. Perinat. Med. 15 (1987) 463

\section{Natural surfactant substitution in respiratory distress syndrome}

\author{
Mikko Hallman ${ }^{1,2}$, Kari Teramo², Olavi Ylikorkala ${ }^{2}$, and T. Allen Merritt ${ }^{3}$ \\ ${ }^{1}$ Department of Pediatrics and ${ }^{2}$ Departments of Obstetrics and Gynecology, Uni- \\ versity of Helsinki, Finland, and ${ }^{3}$ Department of Pediatrics, University of Califor- \\ nia, San Diego, California, U.S.A.
}

\section{Introduction}

Despite advances in perinatal care, serious morbidity among small preterm infants still necessiates pronged, expensive neonatal care. While an increased number of infants with respiratory distress syndrome (RDS) survive, a considerable proportion of them may develop chronic debilitating disease, known as bronchopulmonary dysplasia (BPD) $[18,21]$. Thus, a prevention of the long term morbidity among the small preterm infants with lung immaturity is a great challenge. Since lack of surfactant is the main cause of RDS, surfactant supplementation could be an effective method to prevent the morbidity associated with immaturity. Natural surfactant, applied to immature animal lung causes a striking acute improvement in respiratory function $[1,11,12]$, whereas the synthetic surfactant preparations have had modest acute effects, if any. Following the report of FuJIWARA [4], natural surfactant has been mainly used in clinical trials. Non-randomized studies have demonstrated that surfactant substitution acutely improves the oxygenation and decreases the respiratory support $[3,4,9,24]$. Only well-designed, randomized studies can evaluate objectively the rișks and benefits of surfactant supplementation.

\section{Natural surfactant}

Composition: "Natural" surfactant consists of unique proteins [14] and lipids [6]. Surfactant is considered to be "natural" when its principal components are derived from the lung. Extensive investigation is required to establish a "new" surfactant to be used in therapy [20]. Table I highlights the

Table I. Natural surfactants used in clinical trials.

\begin{tabular}{lllll}
\hline Natural surfactant & Dose & Placebo & Retreatment & Reference \\
\hline $\begin{array}{l}\text { Lipid extract of bovine lung } \\
\text { + synthetic phospholipids }\end{array}$ & $150 \mathrm{mg} / \mathrm{kg}$ & No & No & {$[4]$} \\
$\begin{array}{l}\text { TA-surfactant: lipid extract of a fraction } \\
\text { of bovine lung + synthetic lipids }\end{array}$ & 55 or $108 \mathrm{mg} / \mathrm{kg}$ & No & No & {$[3]$} \\
$\begin{array}{l}\text { Lipid extract of calf lung lavage } \\
\text { Lipid extract of calf lung lavage }\end{array}$ & $100 \mathrm{mg}$ or $75 \mathrm{mg}$ & Air & No & {$[2]$} \\
$\begin{array}{l}\text { Chromatographic fraction of the lipid } \\
\text { extract of porcine or bovine lung }\end{array}$ & $90 \mathrm{mg}$ & Saline & No & {$[15,23]$} \\
$\begin{array}{l}\text { Phospholipid-rich complex from human } \\
\text { amniotic fluid by differential and } \\
\text { density gradient centrifugation }\end{array}$ & $200 \mathrm{mg}$ & No & Yes & {$[19]$} \\
\hline
\end{tabular}


features of the natural surfactants that have been used in clinical trials. Only the human surfactant from amniotic fluid contains the disulfide-linked oligomer, composed of polypeptide units of 35 $\mathrm{kDa}$ ton glycoprotein. This protein enhances the biological activity of synthetic phospholipids, saturated phosphatidylcholine and phosphatidylglycerol [22] and it is a structural component of the tubular myelin [26]. All natural surfactants contain low molecular weight proteolipid(s). The small molecular weight surfactant proteolipids (5-18 kDalton) enhance greatly the surface adsoprtion of phospholipids, thereby allowing saturated phosphatidylcholine to concentrate on interphases and eliminate the surface forces. Liposomes containing synthetic phospholipids and the surfactant proteolipid may approach the activity of the natural surfactant in stabilizing the alveoli of surfactant deficient lungs. Besides the biochemical composition, the biophysical micellar form is another issue that influences the biological activity. Many surfactants, including that from human amniotic fluid, consist mainly of multilamellar structures.

Availability: Heterologous surfactant from animal lungs may become available for treatment of RDS. Human surfactant may be harvested from amniotic fluid and distrivuted from "surfactant banks" for treatment of RDS (figure 1). Human surfactant should be the model for the "natural" surfactant produced by available biomedical techniques in unlimited quantities.

Administration and dosage: According to current practice, surfactant is introduced through an endotracheal tube as a bolus of 3 to $5 \mathrm{ml}$ using a saline vehicle to small preterm infants (table I). In preterm lambs at birth a bolus of $60 \mathrm{mg} / \mathrm{kg}$ resulted in maximal acute improvement in respiratory failure [11]. A similar dose, given in RDS to small preterm infants permanently improved the respiratory function only in $50 \%$ of the cases, whereas in the others the response was unsatisfactory or it vanished resulting in a relapse of respiratory failure [7]. Exogenous surfactant decreased concomitant with the relapse [8]. Altogether 22 out of 31 of immature small preterm infants receiving $60 \mathrm{mg}$ human surfactant within ten minutes of birth required retreatment because of (mostly mild) respiratory failure [17]. Most infants responded favorably to retreatment (figure 2), whereas in $8 \%$ of the infants the alleviation of the respiratory failure was transient despite retreatment. Although the exogenous surfactant disap-

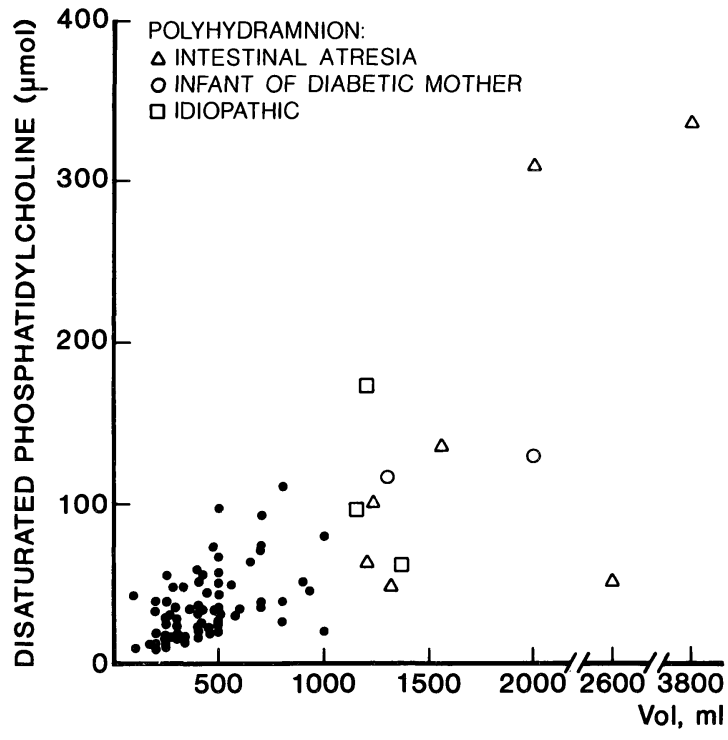

Figure 1. Amount of saturated phosphatidylcholine present in amniotic fluid that was nearly quantitatively recovered by suctioning the amnionic cavity during term cesarean section. In polyhydramnion due to lack of fetal swallowing, there is often large quantities of surfactant, apparently because the major pathway of surfactant elimination via gastrointestinal tract was decreased. The amount of saturated phosphatidylcholine in amniotic fluid correlates closely with the amount of surfactant that can be isolated. A mean of $14 \mathrm{mg}$ surfactant was recovered from amniotic fluid suctioned during term cesarean section. Considering the incidence of the elective term cesarean section with intact membranes $(5-15 \%)$ and of RDS $(0.3-1 \%)$, there should be enough amniotic fluid surfactant for treatment of all cases of RDS.

peared from the airways with a half life of 30 (range 20-36) hours there was no relapse of respiratory failure since the amount of endogenous surfactant in the airways increased [8]. The occasional therapeutic failure can be due to surfactant inhibitors or exceptionally rapid disappearance of exogenous surfactant from the airways. Furthermore, exogenous surfactant does not distribute evenly in peripheral airways in severe lung injury [13].

According to animal studies prophylactic surfactant at birth is more efficacious than surfactant given in respiratory failure [12]. The superiority of "prophylactic" to "rescue" surfactant has not yet been demonstrated in a concurrent clinical trial. 


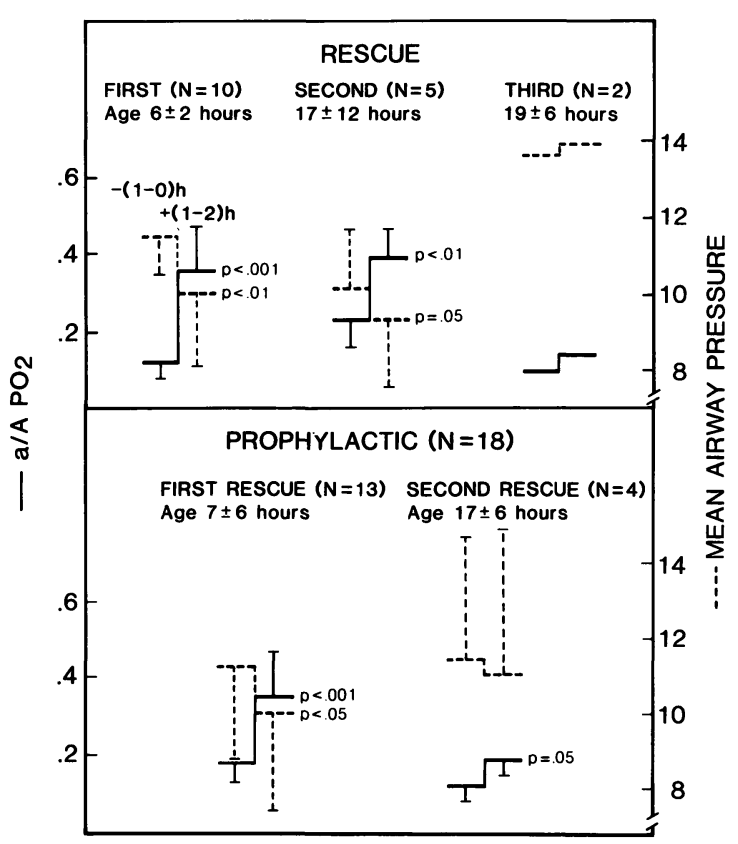

Figure 2. Acute effects of surfactant on the arterial $\mathrm{Po}_{2}$ divided by the alveolar $\mathrm{Po}_{2}\left(\mathrm{a} / \mathrm{A} \mathrm{Po}_{2}\right)$, and on the mean airway pressure $\left(\mathrm{cm} \mathrm{H}_{2} \mathrm{O}\right)$. The data is obtained from patients treated in University Central Hospital, Helsinki. The amount of surfactant in the rescue trial was $60 \mathrm{mg} /$ $\mathrm{kg}$ or a minimum of $60 \mathrm{mg}$, whereas in separate study surfactant was given already at birth using a dose of 60 mg. Retreatment was indicated when fractional inspiratory oxygen requirements exceeded 0.5 , or when increases of peak inspiratory pressures were necessary to maintain adequate $\mathrm{PaO}_{2}$.

\section{Surfactant substitution in management of res- piratory failure}

Randomized clinical trials: Table II lists the present randomized clinical trials thus far. Many others are underway. The infants, who were given bovine surfactant before the first breath had a lower incidence of RDS than the controls who were given air [2]. It is unclear, whether bovine surfactant actually prevented RDS, since the degree of biochemical lung maturity was not studied.

Side effects: The dramatic improvement in gas exchange could be envisioned as having undesirable circulatory consequences. FUJIWARA observed cardiorespiratory failure due to left to right shunting through the patent ductus arteriosus (PDA) following bovine surfactant [3, 4]. Others did not find an increased incidence or severity of

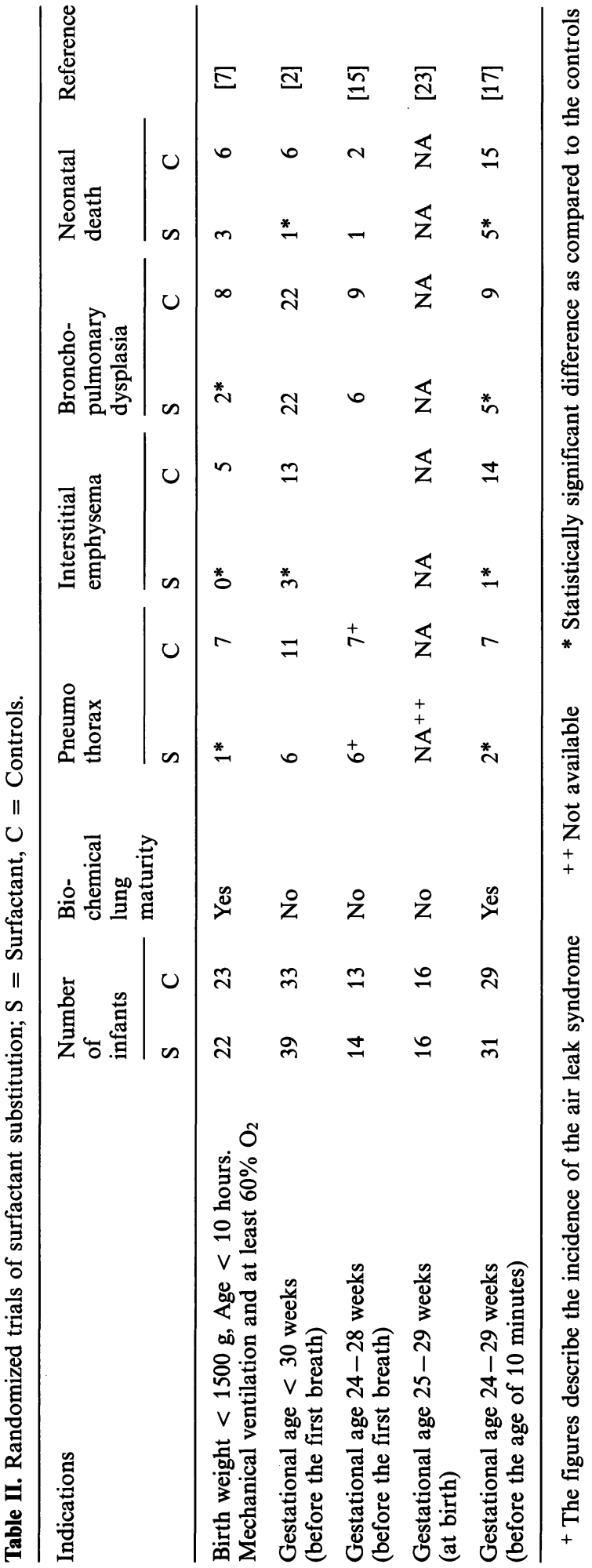


PDA shunting $[2,7,17]$. Indomethacin prior to surfactant did not improve the remission of the respiratory failure [5]. Indeed, the ductus arteriosus may constrict shortly after exogenous surfactant administration. The left to right shunt through PDA needs to be closely surveyed and promptly treated, since the limited reserve of the left ventricle could result in severe cardiac failure, pulmonary edema, and proteinacecous inhibitors "leaking" into the airspaces.

Some patients have demonstrated a transient decrease in the blood pressure following surfactant instillation. This phenomenon may be due to acute vasodilatation, possibly as a result of an oxygeninduced increase in prostacyclin and a decrease in platelet-derived tromboxane (unpublished results). The risk can be eliminated by infusing blood volume expanders before surfactant.

Present evidence suggests that exogenous surfactant does not inhibit the endogenous secretion. Instead, it could provide substates for a rate limiting step in endogenous surfactant synthesis, and stimulate the secretion of endogenous surfactant [8].

Surfactant could conceivably be antigenic when administered intratracheally, thus raising concerns about the potential for sensitization or immunologic injury on infants so treated. STRAYER et al. demonstrated a transient increase in surfactantanti-surfactant immunocomplex formation in RDS regardless whether they had received exogenous human surfactant. This observation suggests that in RDS surfactant gains access to the systemic circulation; however, there was no evidence of immunocomplex-related disease detectable by clinical or by serologic means [25]. No antibodies against exogenous animal surfactant were detected in six survivors with RDS [19]. This issue is still unsettled because of lack of adequate studies.
Antibody formation against surfactant proteins must be rigorously excluded prior to suggesting the safety of heterologous surfactant.

A drug may contain microbes or toxins. All natural surfactants used in clinical trials are reportedly free from bacteria, fungi or even viruses. Today, our human surfactant undergoes heat treatment to eliminate HI virus. No toxic reactions, including pyrogen reactions, have thus far been reported although continuous surveillance is required.

\section{Does surfactant improve the outcome of small pre-} term infants? Randomized trials in small preterm infants have demonstrated that surfactant substitution decreases the occurrence of acute complications, pulmonary interstitial emphysema and pneumothorax (table II). There has been no detectable (i.e. more than $50 \%$ ) decrease in the incidence of intraventricular hemorrhage or PDA, whereas the incidence of death and BPD decreased following human surfactant (table II). Thus far, there are neither published cost benefit analyses nor follow up data.

Possible indications of exogenous surfactant: RDS is a spectrum of diseases involving infants with various degrees of "immaturity" and other abnormalities [6]. In adult respiratory distress syndrome serious surfactant defects are virtually always present, too [10]. Exogenous surfactant has a favorable response in respiratory failure in animals, regardless of the etiology [16]. Therefore, the indications of surfactant therapy can be wider than expected merely on the basis of the trials published at present. It is hoped that the more general availability of surfactant for therapeutic purposes does not result in injudicious practise but instead stimulates research on a wide variety of issues that eventually maximize the benefits and minimize the side effects of this potent therapy.

\section{Summary}

Natural surfactants consist of unique proteins and lipids. Their effectiveness in improving subnormal lung function in surfactant deficiency should be established prior to any clinical trials. Rigorous tests are required to document batch to batch variability in surface activity and to exclude toxic contaminants. Up to this date randomized clinical trials in small preterm infants have

demonstrated a striking improvement in lung function, and a decrease in incidence of acute complications (pneumothorax, interstitial emphysema). Administration of human surfactant at birth or in severe RDS decreased deaths and incidence of bronchopulmonary dysplasia. Although homologous surfactant may not be more advantageous than the heterologous one in terms 
of its acute beneficial effects on lung function, the safety and efficacy of animal surfactant in improving the outcome remains to be established. Human surfactant may serve as a model for unlimited natural surfactant produced by gene technology. The pharmacodynamic aspects of surfactant substitution, the indications of ex- ogenous surfactant, and the management of the patients undergoing surfactant substitution remain to be studied. Exogenous surfactant offers a potential to treat or prevent severe respiratory failure in infants, children and adults.

Keywords: Amniotic fluid, hyaline membrane disease, surfactant.

\section{Zusammenfassung}

\section{Gabe von natïrlichem Surfactant beim Atemnotsyndrom} (RDS)

Der natürliche Surfactant besteht aus ganz bestimmten Proteinen und Lipiden. Deren Effizienz zur Verbesserung einer normalen Lungenfunktion bei Surfactantmangel sollte vor der klinsichen Erprobung bewiesen werden. Es sind strenge Kontrollen notwendig, um Schwankungen hinsichtlich der Oberflächenaktivität bei verschiedenen Produktionsserien zu dokumentieren und toxische Kontaminationen ausschließen zu können. Bei randomisierten klinischen Studien mit kleinen Frühgeborenen zeigte sich eine deutliche Verbesserung der Lungenfunktion und eine geringere Inzidenz akuter Komplikationen (Pneumothorax, interstitielles Emphysem). Nach Gabe von Surfactant vom Menschen bei Geburt oder bei schwerem RDS war die Inzidenz von Todesfäl- len und bronchopulmonalen Dysplasien geringer. $\mathrm{Ob}$ wohl der homologe Surfactant gegenüber dem heterologen im Hinblick auf die akute Verbesserung der Lungenfunktion möglicherweise keine Vorteile bietet, muß die Sicherheit und Effizienz des Surfactants vom Tier zur Verbesserung des neonatalen Zustandes erst noch bewiesen werden. Der Surfactant vom Menschen könnte als Vorlage für die unbegrenzte, gentechnologische Produktion eines natürlichen Surfactants dienen. Pharmakodynamische Aspekte der Surfactantsubstitution, Indikationen für eine exogene Surfactantzufuhr sowie das Management bei Patienten mit Surfactantsubstitution müssen weiter untersucht werden. Der exogene Surfactant stellt ein wirksames Mittel dar zur Behandlung und Prävention schwerer respiratorischer Störungen bei Neugeborenen, Kindern und Erwachsenen.

Schlüsselwörter: Fruchtwasser, hyalines Membransyndrom, Surfactant.

\section{Résumé}

\section{Substitution de surfactant naturel dans le syndrome de détresse respiratoire}

Les surfactants naturels consistent en protéines et en lipides uniques. Leur efficacité à entrainer une fonction pulmonaire subnormale en cas de déficit en surfactant devrait être établie avant tout essai clinique. Des tests rigoureux sont necessaires pour documenter la variabilité lot par lot, dans l'activité de surface et exclure des contaminants toxiques. Jusqu'à cette date des essais cliniques randominés chez de petits enfants prématurés ont démontré une amélioration nette de la fonction pulmonaire et une diminution de l'incidence des complications aiguës (pneumothorax, emphysème interstitiel). L'administration de surfactant humain à la naissance ou lors de SDR graves diminue les morts et l'incidence des dysplasies bronchopulmonaires. Bien que le surfactant homologue ne soit peut être pas plus avantageux que le surfactant hétérologue en terme d'effets aigus bénéfiques sur la fonction pulmonaire, la sécurité et l'efficacité du surfactant animal dans l'amélioration de l'évolution restent à établir. le surfactant humain peut servir de modèle pour le surfactant naturel illimité produit par génie génétique. Les aspects pharmacodynamiques de la substitution de surfactant, les indications du surfactant exogène et la prise en charge des patients necessitant une substitution de surfactant restent à étudier. Le surfactant exogène offre un potentiel de traitement ou de prévention des détresses respiratoires graves chez les nouveauxnés, les enfants et les adultes.

Mots-clés: Liquide amniotique, surfactant, syndrome de détresse respiratoire.

Acknowledgements: Supported by grants from the National Institutes of Health (HL-35036 to T. A. M, M: H.), the Finnish Academy, and the Sigrid Juselius Foundation (M. H.). 


\section{References}

[1] ENHORNING G, B RoBERTSON: Lung expansion in the premature rabbit fetus after tracheal deposition of surfactant. Pediatrics 50 (1972) 58

[2] Enhorning G, A Shennan, F Possmayer, M Dunn, CP Chen, J Milligan: Prevention of neonatal respiratory distress syndrome by tracheal instillation of surfactant: a randomized clinical trial Pediatrics 76 (1985) 145

[3] FujIwara T: Surfactant replacement in neonatal RDS. In: ROBERTSON B, LMG VAN GOLDE, JJ BATENBURG: Pulmonary surfactant. Elsevier, Amsterdam 1984

[4] Fujiwara T, H Maeta, S Chida, T Morita, $Y$ WATABE, T ABE: Artificial surfactant therapy in hyaline-membrane disease. Lancet 1 (1980) 55

[5] Hallman M, TA Merritt, CG Cochrane, L GLUCK: Human surfactant subsitution in severe respiratory distress syndrome. Prog Resp Res 18 (1984) 193

[6] Hallman M, L Gluck: Respiratory distress syndrome - update 1982. Pediatr Clin North Am 29 (1982) 1057

[7] Hallman M, TA Merritt, A-L JarvenpaA, B. Boynton, F Mannino, L Gluck, T Moore, D EDWARDS: Exogenous human surfactant for treatment of revere respiratory distress syndrome: A randomized prospective clinical trial. J Pediatrics 106 (1985) 963

[8] Hallman M, TA Merritt, M Pohjavuori, L GLUCK: Effect of surfactant substitution on lung effluent phospholipids in respiratory distress syndrome. Pediatr Res 20 (1986) 1228

[9] Hallman M, TA Merritt, HA Schneider, BL EPSTEIN, F MANNINO, DK EdWARDS, L GluCK: Isolation of human surfactant from amniotic fluidand a pilot study of its efficacy in respiratory distress syndrome. Pediatrics 71 (1983) 473

[10] Hallman M, R SpragG, JH Harrell, KM Moser, L GLUCK: Evidence of lung surfactant abnormality in respiratory failure. Study of bronchoalveolar lavage phospholipids, surface activity, phospholipase activity, and plasma myoinositol. J Clin Invest 70 (1982) 673

[11] Ikegami M, FH Adams, B Towers, AB Osher: The quantity of natural surfactant necessary to prevent the respiratory distress syndrome in premature lambs. Pediatr Res 14 (1980) 1082

[12] Jobe A, M Ikegami, T Glatz, Y Yoshida, E DiakOMANOLIS, J PADBURY: Duration and characteristics of treatment of premature lambs with natural surfactant. J Clin Invest 67 (1981) 370

[13] Jobe A, M IKEgAMI, H JACOBS, S JoNes: Surfactant and pulmonary blood flow distribution following treatment of premature lambs with natural surfactant. J Clin Invest 73 (1984) 848

[14] KING, RJ: The apolipoproteins of pulmonary surfactant. Prog Resp Res 18 (1984) 68

[15] KWONG MS, EA Egan, RH NotTER, DL ShapiRo: Double-blind clinical trial of calf lung surfactant extract for the prevention of hyaline membrane disease in extremely premature infants. Pediatrics 76 (1985) 585

[16] Lachmann B, E DanzmanN: Adult respiratory distress syndrome. In: ROBERTSON B, LMG VAN Golde, JJ BATENBURG: Pulmonary surfactant. Elsevier, Amsterdam 1984

[17] Merritt TA, M Hallman, BT Bloom, C Berry, K. BenirschKe, O SAhn, T Key, D Edwards, AL JARVENPAa, M PoHJaVUOR, K KanKaANPaA, M Kunnas, H PaAtero, J Rapola, J JaAskelainen: Prophylactic treatment of very premature infants with human surfactant. New Engl J Med 315 (1986) 785

[18] Merritt TA, CG Cochrane, K Holcomb, B Bohl, M Hallman, D Strayer, DK EdWARDS, L GluCK: Elastase and $\alpha_{1}$-proteinase inhibitor activity in tracheal aspirates during respiratory distress syndrome. Role of inflammation in the pathogenesis of bronchopulmonary dysplasia. J Clin Invest 72 (1983) 656

[19] Nohara K, P Bergren, $T$ Curstedt, G Grossmann, R NiLSSON, B Robertson: Correlations between physical and physiological properties of various preparations of lung surfactant. Submitted for publication

[20] Nohara K, P Bergren, $T$ Curstedt, G GrossmanN, R NiLSSON, B RoBertson: Correlations between physical and physiological properties of various preparations of lung surfactant. Eur $\mathbf{J}$ Respir Dis 3 (1986)

[22] RevaK SD, TA Merritt, M Hallman, CG COCHRANE: Reconstitution of surfactant activity using purified human apoprotein and phospholipids measured in vitro and in vivo. Am Rev Respirat Dis 134 (1986) 1258

[23] Shapiro DL, RH Notter, FC Morin, KS DeLungA, LM Golub, RA Sinkin, KI Weiss, C Cox: Double-blind, randomized trial of a calf lung surfactant extract administered at birth to very premature infants for prevention of respiratory distress syndrome. Pediatrics 76 (1985) 593

[24́ Smyth JA, IL Metcalfe, P Duffy, F Possmayer, MH BRYAN, G ENHORNING: Hyaline membrane disease treated with bovine surfactant. Pediatrics 71 (1983) 913

[25] Strayer DS, TA Merritt, JL Lwebuga-Mukasa, M Hallman: Surfactant-anti-surfactant immune complexes in infants with respiratory distress syndrome. Am J Pathol 122 (1986) 353

[26] Williams MC, BJ Benson: Immunochemical localization and identification of the major surfactant protein in adult rat lung. $\mathbf{J}$ Histochem Cytochem 29 (1981) 291

Mikko Hallman, M. D.

Childrens Hospital, University of Helsinki

Stenbäckinkatu 11

00290 Helsinki, Finland 